\title{
Vanadium(V) Oxoanions in Basic Water Solution: a Simple Oxidative System for the One Pot Selective Conversion of L-Proline to Pyrroline-2-Carboxylate
}

\author{
Lorenzo Biancalana, ${ }^{a}$ Giada Tuci, ${ }^{a}$ Fabio Piccinelli, ${ }^{b}$ Fabio Marchetti, ${ }^{a, s}$ Marco Bortoluzzi, ${ }^{\mathrm{c}, *}$ and Guido Pampaloni ${ }^{a, *}$ \\ ${ }^{a}$ University of Pisa, Dipartimento di Chimica e Chimica Industriale, Via G. Moruzzi 13, I-56124 Pisa, Italy. Tel: +39 050 2219245. E-mail: \\ guido.pampaloni@unipi.it.Webpage: http://www.dcci.unipi.it/guido-pampaloni.html. \\ ${ }^{b}$ University of Verona, Solid State Chemistry Laboratory-DB, Strada le Grazie 15, 37134, Verona, Italy \\ ${ }^{c}$ Ca' Foscari University of Venice, Dipartimento di Scienze Molecolari e Nanosistemi, Via Torino 155, I-30175 Mestre (Venezia), Italy
}

This submission was created using the RSC Article Template (DO NOT DELETE THIS TEXT)

(LINE INCLUDED FOR SPACING ONLY - DO NOT DELETE THIS TEXT)

The unprecedented, direct chemical oxidation of L-proline to pyrroline-2-carboxylate was achieved in water $(\mathrm{pH}$ ca. 10$)$ by $\mathrm{means}$ of $\mathrm{NH}_{4} \mathrm{VO}_{3} / \mathrm{NH}_{3}$ or $\mathrm{V}_{2} \mathrm{O}_{5} / \mathrm{MOH}(\mathrm{K}=\mathrm{Na}, \mathrm{K})$, and the anion was fully characterized as ammonium or alkaline metal salts. Quantitative yield and higher atom economy performance were supplied with the latter system, the alkaline salts being more stable than the ammonium one. Different mixed valence $\mathrm{V}(\mathrm{IV}) / \mathrm{V}(\mathrm{V})$ compounds precipitated from the reaction mixtures depending on the nature of the employed base. A possible reaction mechanism is proposed according to DFT calculations. The analogous reaction of trans-4-hydroxy-L-proline with $\mathrm{NH}_{4} \mathrm{VO}_{3} / \mathrm{NH}_{3}$ afforded pyrrole-2-carboxylic acid in $81 \%$ yield, while sarcosine underwent prevalent decomposition under similar experimental conditions. Instead, no reaction was observed with primary (glycine, L-alanine, L-phenylalanine) and tertiary $\alpha$-amino acids ( $N, N$-dimethyl-L-phenylalanine, $N, N$-dimethylglycine).

\section{Introduction}

$\alpha$-Imino acids are intermediates in the Strecker degradation of $\alpha$-amino acids (see Scheme 1). ${ }^{1}$ This decarboxylative oxidation process is promoted by a variety of inorganic and organic agents and plays a key role in food chemistry. ${ }^{2}$ As a direct consequence, $\alpha$-imino acids are relatively unstable substrates and only a few of them have been isolated. ${ }^{3}$

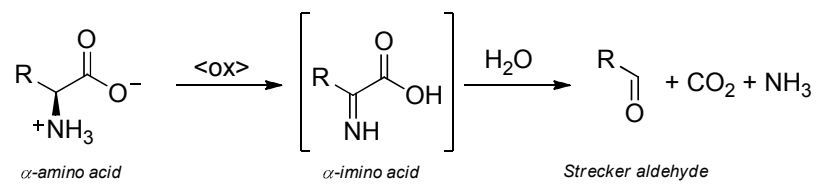

Scheme 1. The Strecker degradation of a generic primary $\alpha$-amino acid.

Among this class of compounds, pyrroline-2-carboxylic acid, HP2C (conjugate base: pyrroline-2-carboxylate, $\mathrm{P}^{-} \mathrm{C}^{-}$) has aroused interest for its biochemical role ${ }^{4}$ and utility in organic synthesis. ${ }^{5}$ This $\alpha$-imino acid has been obtained in solution by the cyclization of 5-amino-2oxopentanoic acid in water ${ }^{6}$ or its $N-\mathrm{C}(=\mathrm{X}) \mathrm{NH}_{2}$ derivatives $(\mathrm{X}=\mathrm{O}$, $\mathrm{NH}$ ) in trifluoroacetic acid. ${ }^{7}$ However, it is more desirable to obtain $\mathrm{P}^{2} \mathrm{C}^{-}$from a cheap and natural starting material such as L-proline.

To the best of our knowledge, the direct conversion of L-Proline to $\mathrm{HP} 2 \mathrm{C}$ has been achieved only via enzymatic routes (Scheme 2$){ }^{8}$ In fact, classic Strecker degradation agents, such as ninhydrin or 1,2dicarbonyl compounds, do not react with L-proline as well as other secondary amino acids. ${ }^{1}$ On the other hand, the oxidation of L-Proline by organic oxidants, such as $N$-bromosuccinimide in water ${ }^{9}$ or iodosylbenzene in various solvents, ${ }^{10}$ yields 2 -pyrrolidinone. The same product has been obtained by treatment of L-proline with $\mathrm{NaIO}_{4}$ in aqueous $\mathrm{H}_{2} \mathrm{SO}_{4}(\mathrm{pH}=2){ }^{11}$ Alkaline $\mathrm{KMnO}_{4}$ reacts with L-Proline affording 4-aminobutanal, i.e. the corresponding Strecker aldehyde. ${ }^{12}$

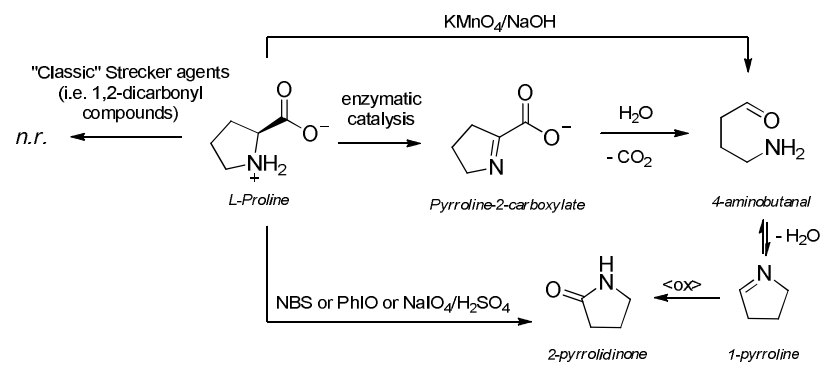

Scheme 2. Overview of oxidation reactions of L-proline.

A selective dehydrogenation at the $\mathrm{CH}-\mathrm{NH}$ position of L-Proline without undesirable side reactions (such as decarboxylation and overoxidation of the product) was achieved only using protecting strategies on the $\alpha$-amino acid. For instance, sodium pyrroline-2-carboxylate has been isolated with a five-step synthesis involving the preparation of $\mathrm{L}$ Proline methyl ester, oxidation with ${ }^{t} \mathrm{BuOCl}$ and final basic hydrolysis of the ester. ${ }^{5}$ A second multistep synthesis of the sodium salt $\mathrm{Na}[\mathrm{P} 2 \mathrm{C}]$ has been reported, involving coordination of L-proline to $\mathrm{Cu}(\mathrm{II})$, oxidation of the coordinated ligand by $\mathrm{MnO}_{2} / \mathrm{H}_{2} \mathrm{O}_{2}$ and dissociation of the $\alpha$-imino acidate ligand performed with an anion-exchange resin. ${ }^{13}$ The possible use of transition metals as "protecting groups" for this synthesis is limited by the fact that pyrroline-2-carboxylate is a good $\mathrm{N}, \mathrm{O}$-chelating ligand ${ }^{14}$ and it is therefore difficult to dissociate from the metal centre at the end.

In the light of the possible roles played by vanadium in living organisms, ${ }^{15}$ the interaction of vanadium ions with $\alpha$-amino acids and oligo-peptides in water medium has aroused a considerable attention. ${ }^{16}$ However, vanadium $(V)$ is known to exhibit a poor affinity towards $\alpha$ amino acids in aqueous solution ${ }^{17}$ (unless peroxo ${ }^{18}$ or hydroxylamido ${ }^{19}$ ions are present) and only one (not fully characterized) oxovanadium(V)-amino acid complex has been isolated so far. ${ }^{20}$ Moreover, the orthovanadate ion, $\left[\mathrm{VO}_{4}\right]^{3-}$, is isoelectronic with other oxo-metallate ions of the first transition series, such as $\left[\mathrm{MnO}_{4}\right]^{-}$and $\left[\mathrm{CrO}_{4}\right]^{2-}$, but the former is featured by a significantly lower electrochemical reduction potential. ${ }^{21}$ Therefore, we reckoned that vanadium $(\mathrm{V})$ was an interesting candidate in order to explore its oxidation chemistry towards $\alpha$-amino acids. 
In this paper, we report on the reactions of a series of $\alpha$-amino acids with $\mathrm{V}(\mathrm{V})$ species in alkaline medium, providing a route for the one pot proline to pyrroline-2-carboxylate conversion.

\section{Results and Discussion}

Conversion of L-proline to pyrroline-2-carboxylate: reaction optimization and solid state isolation of $\mathrm{M}[\mathrm{P2C}], \mathrm{M}=\mathrm{Na}, \mathrm{K}$.

Ammonium vanadate was initially studied as a commercially available, possible oxidative agent respect to L-proline. Thus, when mixtures of $\mathrm{NH}_{4} \mathrm{VO}_{3}$ and L-proline in water were treated with ammonia and heated at $70^{\circ} \mathrm{C}$ for $24-48$ hours, a redox reaction took place. The resulting dark coloured solutions were investigated by NMR spectroscopy, revealing the selective oxidation (dehydrogenation) of L-proline to the corresponding $\alpha$-imino acidate $\left(\mathrm{P}^{-} \mathrm{C}^{-}\right)$, Scheme 3a. The black precipitate, separated by filtration, was characterized by XRPD, which indicated the presence of the mixedvalence $\mathrm{V}(\mathrm{V})-\mathrm{V}(\mathrm{IV})$ salt $\left(\mathrm{NH}_{4}\right)_{2} \mathrm{~V}_{3} \mathrm{O}_{8}$ in mixture with unreacted $\mathrm{NH}_{4} \mathrm{VO}_{3}$ (see Figure $\mathrm{S} 1$ given as Supporting Information).

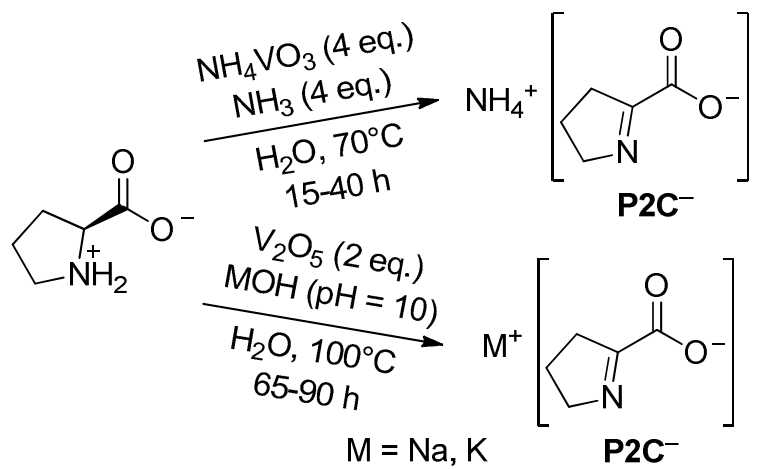

Scheme 3. V(V)-mediated one pot conversion of L-proline to pyrroline-2-carboxylate ( $\mathrm{P}^{-} \mathrm{C}^{-}$).

The formation of $\mathrm{P}_{2} \mathrm{C}^{-}$in the $\mathrm{NH}_{4} \mathrm{VO}_{3} / \mathrm{NH}_{3} / \mathrm{L}$-proline system was investigated by varying the ratios between the reactants (see Experimental and Table S1 given as Supporting Information).

It should be noted that the initial $\mathrm{pH}$ of reaction mixtures was not measured: the $\mathrm{pH}$ value decreased over time due to the progressive dissolution of $\mathrm{NH}_{4} \mathrm{VO}_{3}$ (not completely soluble under the selected conditions). Therefore, representative $\mathrm{pH}$ values corresponding to a given $\mathrm{NH}_{3} / \mathrm{NH}_{4} \mathrm{VO}_{3}$ molar ratio were determined by $\mathrm{NH}_{3}$ titration of a dilute solution of $\mathrm{NH}_{4} \mathrm{VO}_{3}$ (Figure S2). The redox process occurred only within a limited window of $\mathrm{pH}$ values (modified via the $\mathrm{NH}_{3} / \mathrm{NH}_{4} \mathrm{VO}_{3}$ ratio); this fact may be related to the $\mathrm{pH}$-dependent speciation of vanadates in solution. ${ }^{21 b, 22}$

The optimal reaction parameters were established to be $\mathrm{NH}_{3} / \mathrm{NH}_{4} \mathrm{VO}_{3}$ ratio $=1$ (corresponding to $\mathrm{pH}=9.8$ for a dilute solution), $\mathrm{NH}_{4} \mathrm{VO}_{3} / \mathrm{L}$-proline ratio $=4$ and vanadium loading $=1.0$ mol L ${ }^{-1}$ (see Table $\mathrm{S} 1$ for details). Assuming $\left(\mathrm{NH}_{4}\right)_{2} \mathrm{~V}_{3} \mathrm{O}_{8}$ as the only vanadium product, the stoichiometry requires six $\mathrm{V}(\mathrm{V})$ ions per L-proline, two of them undergoing reduction to $\mathrm{V}(\mathrm{IV})$ and the other four being incorporated within $\left(\mathrm{NH}_{4}\right)_{2} \mathrm{~V}_{3} \mathrm{O}_{8}$ (Equation 1). A partial aerobic re-oxidation of $\mathrm{V}(\mathrm{IV})$ to $\mathrm{V}(\mathrm{V})$ may account for the discrepancy between theoretical (6) and experimental (4) value of the optimal $\mathrm{NH}_{4} \mathrm{VO}_{3} / \mathrm{L}$-proline ratio.

$$
\begin{aligned}
& 6 \mathrm{NH}_{4} \mathrm{VO}_{3}+\mathrm{C}_{5} \mathrm{H}_{9} \mathrm{NO}_{2} \rightarrow\left(\mathrm{NH}_{4}\right)\left[\mathrm{C}_{5} \mathrm{H}_{6} \mathrm{NO}_{2}\right]+\mathrm{NH}_{3}+ \\
& 2 \mathrm{H}_{2} \mathrm{O}+2\left(\mathrm{NH}_{4}\right)_{2} \mathrm{~V}_{3} \mathrm{O}_{8}
\end{aligned}
$$

Under the optimized conditions, a $\mathrm{P}^{-} \mathrm{C}^{-}$yield of $55 \%$ in solution was obtained after $25 \mathrm{~h}$ at $70^{\circ} \mathrm{C}$ (entry \#14 in Table S1). However, the thermal and vacuum instability of ammonium pyrroline-2-carboxylate prevented the yield from reaching higher values, and the isolation of the salt in the solid state.

These drawbacks were overcome by cation exchange, from $\mathrm{NH}_{4}{ }^{+}$to $\mathrm{Na}^{+}$or $\mathrm{K}^{+}$. In fact, the quantitative formation of $\mathrm{M}[\mathrm{P} 2 \mathrm{C}](\mathrm{M}=\mathrm{Na}, \mathrm{K})$ was achieved when $2: 1 \mathrm{~mol} / \mathrm{mol}$ mixtures of $\mathrm{V}_{2} \mathrm{O}_{5}$ and L-proline were treated with $\mathrm{MOH}$ up to $\mathrm{pH}=10$ and then heated at reflux temperature for 67 or 90 hours, respectively (Scheme 3b).

Sodium and potassium pyrroline-2-carboxylate could be isolated as ivory-white crystalline materials in low to moderate yields, allowing the full spectroscopic characterization of the anion (IR, UV-Vis, ${ }^{1} \mathrm{H}$ and ${ }^{13} \mathrm{C}$ NMR). To the best of our knowledge, the potassium salt is unprecedented, while $\mathrm{Na}[\mathrm{P} 2 \mathrm{C}]$ was previously obtained only by multistep synthetic protocols. 5,13

The black precipitates, filtered off at the end of the reaction, were identified as $\mathrm{V}(\mathrm{IV})-\mathrm{V}(\mathrm{V})$ species $\mathrm{NaV}_{2} \mathrm{O}_{5}$ (XRPD (figure 1), spectroscopic and analytical techniques) and $\mathrm{K}_{2} \mathrm{~V}_{3} \mathrm{O}_{8}$ (spectroscopic and analytical techniques), respectively. The observed XRPD pattern corresponding to $\mathrm{NaV}_{2} \mathrm{O}_{5}$ is shown in Figure 1 .

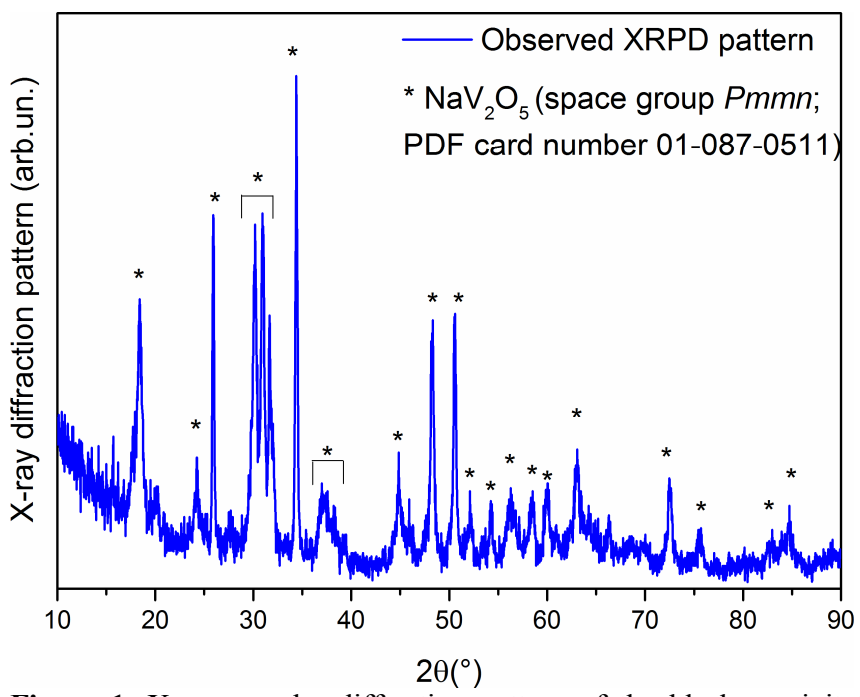

Figure 1. X-ray powder diffraction pattern of the black precipitate from the reaction of $\mathrm{V}_{2} \mathrm{O}_{5}$ with L-proline in aqueous $\mathrm{NaOH}$ solution at $\mathrm{pH}=10$. Reference PDF card from ref. 23 .

To the best of our knowledge, the reactions reported in Scheme 3 represent the first example of direct chemical oxidation of L-proline to pyrroline-2-carboxylate, avoiding the use of group-protecting strategies. It is worthy to note that, in every cases, vanadium complexes with either L-proline or $\mathrm{P}^{2} \mathrm{C}^{-}$were not detected in solution or in the solid state, thus confirming the reluctance of vanadates to bind monoanionic $N, O$ ligands (see Introduction). ${ }^{17}$

A series of oxidants have been reported to promote the oxidation of Lproline to products different from $\mathrm{P}_{2} \mathrm{C}^{-}$(see Introduction). In order to expand the knowledge on the oxidation chemistry of L-proline in water, and to see the possibility of performing the transformation to P2 $\mathrm{C}^{-}$by oxidant species alternative to $\mathrm{V}(\mathrm{V}), \mathrm{H}_{2} \mathrm{O}_{2}$ and $\mathrm{Ce}\left(\mathrm{SO}_{4}\right)_{2}$ were tested under similar experimental conditions. While no reaction occurred in the presence of cerium(IV) sulfate, the reaction of Lproline with hydrogen peroxide gave a 81/19 mixture of succinimide and succinic anhydride (Scheme 4). This outcome reinforces the idea that $\mathrm{V}(\mathrm{V})$ holds unique features so to make possible the direct Lproline to $\mathrm{P} 2 \mathrm{C}^{-}$conversion.

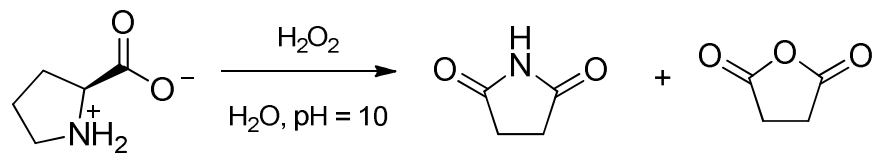

Scheme 4. Oxidation reaction of L-proline with $\mathrm{H}_{2} \mathrm{O}_{2}$.

L-Proline to P2C ${ }^{-}$conversion: DFT study. 
Possible intermediates in the selective oxidation of L-proline by V(V) were studied by means of DFT calculations, considering water as continuous medium. One $\mathrm{H}_{2} \mathrm{O}$ molecule was explicitly added to the computational models.

According to ${ }^{51} \mathrm{~V}$ NMR spectroscopy, polynuclear V(V) oxo-anions may be generated in water under the experimental conditions described above (see Figures S3 and S4), ${ }^{22}$ and a model based on four vanadium centres was chosen to balance the computational requests and the reliably of the simulations.

All the attempts to computationally obtain coordination compounds between the conjugate base of L-proline and $\left[\mathrm{V}_{4} \mathrm{O}_{12}\right]^{4-}$ or $\left[\mathrm{V}_{4} \mathrm{O}_{11}(\mathrm{OH})\right]^{3-}$ were unsuccessful because of the electrostatic repulsion between L-prolinate and the anions. On the other hand, a complex was obtained using $\left[\mathrm{V}_{4} \mathrm{O}_{10}(\mathrm{OH})_{2}\right]^{2-}$ as a reactant. It has to be highlighted that the protonation of $\left[\mathrm{V}_{4} \mathrm{O}_{12}\right]^{4-}$ up to $\left[\mathrm{V}_{4} \mathrm{O}_{10}(\mathrm{OH})_{2}\right]^{2-}$ resulted thermodynamically viable from preliminary DFT calculations, while the formation of $\left[\mathrm{V}_{4} \mathrm{O}_{9}(\mathrm{OH})_{3}\right]^{-}$is unlikely in basic solution. ${ }^{24}$

The generation of $\left[\mathrm{V}_{4} \mathrm{O}_{10}(\mathrm{OH})_{2} \text { (L-prolinate) } \mathrm{H}_{2} \mathrm{O}\right]^{3-}$ (A, Figure 2) from $\left[\mathrm{V}_{4} \mathrm{O}_{10}(\mathrm{OH})_{2} \cdot \mathrm{H}_{2} \mathrm{O}\right]^{2-}$ and L-prolinate is favourable, being the corresponding Gibbs energy variation about $-11.8 \mathrm{kcal} \mathrm{mol}^{-1}$ at 343.15 $\mathrm{K}$. The optimized geometry of $\mathbf{A}$ is shown in Figure 2. The coordination involves the carboxylate moiety, which is $\kappa^{1}$-bonded to a vanadium centre. The $\mathrm{V}-\mathrm{O}_{\text {carboxylate }}$ distance is $2.056 \AA$. The interaction of L-prolinate with the metal anion is enforced by a hydrogen bond between the other oxygen atom of the carboxylate group and a bridging hydroxo ligand $\left(\mathrm{O}_{\text {carboxylate }}--\mathrm{H}, 1.565 \AA\right.$; $\mathrm{O}-\mathrm{H}$, $1.007 \AA)$. On the other hand, the $\mathrm{NH}$ fragment does not appear involved in any meaningful interaction. The cyclic structure of the polyoxovanadate is maintained after coordination, even though one vanadium centre is five-coordinated.

The most likely subsequent intermediate involves the one-electron transfer from coordinated L-prolinate to the polyoxo anion, to obtain the triplet state geometry $\mathbf{B}$ depicted in Figure 2. The Gibbs energy variation is only slightly positive, around $5.9 \mathrm{kcal} \mathrm{mol}^{-1}$. The presence of a V(IV) centre, bound to L-prolinate, is confirmed by the spin density surface shown in Figure 2. The amino acidate ligand has radical character, and the unpaired electron is mainly localized on the nitrogen atom. The coordination mode of the amino acidate is comparable to that already described for intermediate $\mathbf{A}$, but it has to be remarked that the oxidation of the ligand is accompanied by hydrogen migration from the nitrogen atom to one of the oxo-ligands, converting into a terminal hydroxo.

Another hydrogen migration from L-prolinate to the polyoxovanadate could afford intermediate $\mathbf{C}$ (Figure 2). The relative orientation of the L-prolinate ligand with respect to the polyoxometalate skeleton makes scarcely probable the direct H-migration from the carbon atom in alpha position. On the other hand, the hydrogen atoms of the $\mathrm{N}$ bonded $\mathrm{CH}_{2}$ should be quite acidic because of their closeness to the electron-poor nitrogen. The hydrogen migration from the $\mathrm{CH}_{2}$ group causes the conversion of another oxo-ligand to a terminal hydroxo-. The formation of $\mathbf{C}$ from $\mathbf{B}$ is accompanied by a strongly negative Gibbs energy variation, $-34.7 \mathrm{kcal} \mathrm{mol}^{-1}$. A detailed investigation of the geometry optimization steps affording $\mathbf{C}$ suggests that a water molecule takes part to the proton transfer. As highlighted by the spin density surface of $\mathbf{C}$, a second electron transfer accompanies the hydrogen migration. The intermediate is a pyrroline-5-carboxylate ( $\mathrm{P}^{-} \mathrm{C}^{-}$) complex of a polyoxovanadate containing two V(IV) centres, bridged by a $\mathrm{OH}-$ ligand. The coordination mode by the carboxylate group is the same as that described for the intermediates $\mathbf{A}$ and $\mathbf{B}$.

The simple dissociation of the ligand from the polyoxo anion is not favourable, but the $\mathrm{P}^{-} \mathrm{C}^{-}$anion may be displaced by water to form $\mathbf{D}$ (Figure 2). Even if the simple reaction depicted in Figure 2 has positive $\Delta \mathrm{G}$, we must consider the concentration of water, the alkaline $\mathrm{pH}$ and therefore the presence of $\mathrm{OH}^{-}$ions as good nucleophiles, and the decomposition of the final mixed-valence compound to unsolvable species as presumable driving forces. The tautomerization of pyrroline-5-carboxylate to the final pyrroline-2-carboxylate is favourable by about $3.5 \mathrm{kcal} \mathrm{mol}^{-1}$.

\section{Figure 2 about here}

Figure 2. DFT-optimized structures of possible intermediates involved in the oxidation of L-prolinate to pirrolidine-2-carboxylate and relative Gibbs energy values ( $\mathrm{kcal} \mathrm{mol}^{-1}, \mathrm{~T}=343.15 \mathrm{~K}$ ). C-PCM $/ \omega \mathrm{B} 97 \mathrm{X}$ calculations, water as continuous medium. Colour map: light grey, hydrogen; dark grey, carbon; red, oxygen; blue, nitrogen; green, vanadium, light blue, spin density surface (isovalue $=0.01$ a.u.). Cartesian coordinates of the DFT-optimized structures are collected in a separated. xyz file.

\section{Substrate scope and mechanistic investigation.}

Considering the results described in the previous paragraph, we were interested to see whether the observed $\mathrm{V}(\mathrm{V})$-oxidation of proline could be extended to other $\alpha$-amino acids. Therefore, a series of $\alpha$-amino acids (Scheme 5) were allowed to react with $\mathrm{NH}_{4} \mathrm{VO}_{3}$ under the conditions optimized for L-proline (4 eq. $\mathrm{NH}_{3}, 4$ eq. $\mathrm{NH}_{4} \mathrm{VO}_{3}, 70{ }^{\circ} \mathrm{C}, 40 \mathrm{~h}$ ). No reaction was observed with $\alpha$-amino acids having tertiary amino groups ( $N, N$-Dimethyl-Lphenylalanine, $N, N$-dimethylglycine), as expected since $\mathrm{C}=\mathrm{N}$ bond formation for these substrates would imply the breaking of carbonnitrogen bonds. On the other hand, reaction mixtures of secondary $\alpha$-amino acids ( $N$-methylglycine (sarcosine), trans-4-hydroxy-Lproline) rapidly turned black followed by the precipitation of $\left(\mathrm{NH}_{4}\right)_{2} \mathrm{~V}_{3} \mathrm{O}_{8}$ as found for L-proline (Scheme 3a). Pyrrole-2carboxylic acid was isolated in $81 \%$ yield from trans-4-hydroxy-Lproline after acidification of the reaction mixture with $\mathrm{HCl}$ and subsequent $\mathrm{Et}_{2} \mathrm{O}$ extraction (Scheme $5 \mathrm{~b}$ ). This product was previously obtained by the oxidation of trans-4-hydroxy-L-proline with $\mathrm{CuSO}_{4} / \mathrm{H}_{2} \mathrm{O}_{2}{ }^{25}$ The formation of the aromatic pyrrole ring is probably the driving force for the dehydrogenation-dehydration of the $\alpha$-amino acid. On the other hand, the oxidation of sarcosine by $\mathrm{NH}_{3} / \mathrm{NH}_{4} \mathrm{VO}_{3}$ was not selective, yielding methylammonium and several unidentified species deriving from the $\left[\mathrm{CH}_{2} \mathrm{CO}_{2}{ }^{-}\right]$fragment (Scheme 5c). DFT calculations indicate that the coordination mode of the sarcosinate anion to $\left[\mathrm{V}_{4} \mathrm{O}_{10}(\mathrm{OH})_{2} \cdot \mathrm{H}_{2} \mathrm{O}\right]^{2-}$ should be analogous to that discussed for L-prolinate (see Figure S5).

Surprisingly, reaction attempts involving primary $\alpha$-amino acids (glycine, L-alanine, L-phenylalanine) led to clean recovery of the starting materials (Scheme 5a).

a)

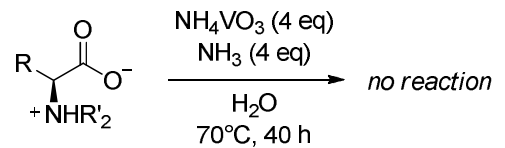

$\mathrm{R}^{\prime}=\mathrm{H} ; \mathrm{R}=\mathrm{H}, \mathrm{Me}, \mathrm{CH}_{2} \mathrm{Ph}$

$\mathrm{R}^{\prime}=\mathrm{Me} ; \mathrm{R}=\mathrm{H}, \mathrm{CH}_{2} \mathrm{Ph}$

b)

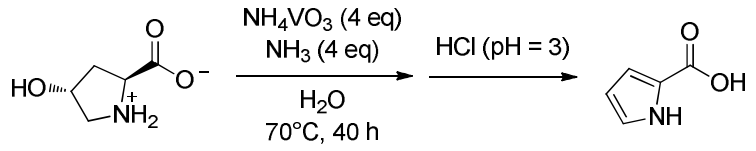

c)

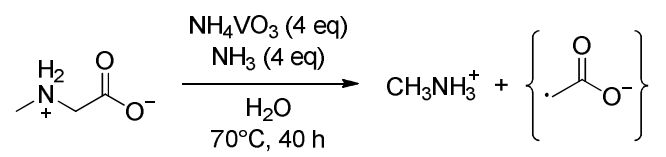

Scheme 5. V(V)-mediated conversion of b) trans-4-hydroxy-L-proline to pyrrole-2-carboxylate and c) sarcosine to methylammonium. No reaction was observed with primary or tertiary $\alpha$-amino acids (a).

In order to find a possible explanation for the lack of reactivity of primary $\alpha$-amino acids, a DFT study was carried out by choosing glycine as a representative compound. On theoretical grounds, the coordination of glycinate to $\left[\mathrm{V}_{4} \mathrm{O}_{10}(\mathrm{OH})_{2} \cdot \mathrm{H}_{2} \mathrm{O}\right]^{2-}$ resembles that described for L-prolinate (Figure 3, intermediate E). Nevertheless, the formation of the corresponding triplet state (intermediate $\mathbf{F}$ in Figure 3) requires more energy $\left(\Delta \mathrm{G}=12.6 \mathrm{kcal} \mathrm{mol}^{-1}\right)$. More 
important, the required, subsequent hydrogen migration may involve only the alpha-carbon and it is, differently from the case of L-prolinate, not thermodynamically favourable $\left(\Delta \mathrm{G}=3.5 \mathrm{kcal} \mathrm{mol}^{-}\right.$ $\left.{ }^{1}\right)$. In the resulting species (intermediate $\mathbf{G}$ in Figure 3), the organic ligand maintains its radical character, and only one metal centre has been reduced to V(IV). In summary, the more difficult V(V)oxidation of glycinate with respect to prolinate is presumably at the basis of the different reactivities observed with these two $\alpha$-amino acids.

\section{Figure 3 about here}

Figure 3. DFT-optimized structures of possible intermediates in the interaction of glycinate with $\left[\mathrm{V}_{4} \mathrm{O}_{10}(\mathrm{OH})_{2} \cdot \mathrm{H}_{2} \mathrm{O}\right]^{2-}$ and relative Gibbs energy

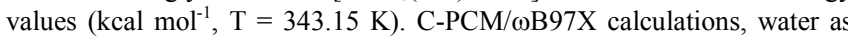
continuous medium. Colour map: light grey, hydrogen; dark grey, carbon; red, oxygen; blue, nitrogen; green, vanadium, light blue, spin density surface (isovalue $=0.01$ a.u.). Cartesian coordinates of the DFT-optimized structures are collected in a separated .xyz file.

To shed more light on the mechanism of oxidation of secondary $\alpha$ amino acids by $\mathrm{V}(\mathrm{V})$, the reactions with L-proline and trans-4hydroxy-L-proline were then performed in $\mathrm{D}_{2} \mathrm{O}$. In the case of $\mathrm{L}-$ proline, 3,3-dideutero-1-pyrroline-2-carboxylate $\left(\mathrm{P} 2 \mathrm{C}-\mathrm{d}_{2}{ }^{-}\right)$was NMR identified in solution at the end of the reaction. The incorporation of deuterium in the $\mathrm{C} 3$ position of $\mathrm{P}_{2} \mathrm{C}^{-}$has been previously observed and associated to a fast equilibrium occurring between the cyclic imino and acyclic oxo-amino species in solution. ${ }^{26}$ However the yield of $\mathrm{P} 2 \mathrm{C}-\mathrm{d}_{2}{ }^{-}(35 \%$ after $30 \mathrm{~h})$ was significantly lower than that of $\mathrm{P}^{2} \mathrm{C}^{-}$under the same conditions $(55 \%$ after $25 \mathrm{~h})$. The replacement of ${ }^{1} \mathrm{H}$ with ${ }^{2} \mathrm{H}$ in the $\mathrm{O}-\mathrm{H}$ and $\mathrm{N}-\mathrm{H}$ bonds of the intermediates in Figure 2 caused negligible changes of the relative energy values calculated by DFT (see Figure S6). The slower rate of the reaction can be therefore explained by supposing that, in the rate-determining transition state, E-hydrogen bond breaking occurs, preceded by H/D exchange.

Conversely, the reaction of trans-4-hydroxy-L-proline in $\mathrm{D}_{2} \mathrm{O}$ afforded pyrrole-2-carboxylic acid, without incorporation of deuterium, in the same yield as in the $\mathrm{H}_{2} \mathrm{O}$ experiment. These facts suggest that the mechanism of oxidation of L-proline and its 4-hydroxy analogue are different, and that hydrogen bonding may play a key role in the formation of pyrroline-2-carboxylate. ${ }^{27}$ Another indication in this sense was obtained by using $\mathrm{Et}_{3} \mathrm{~N}$ as a base: no reaction between $\mathrm{V}_{2} \mathrm{O}_{5}$ and L-proline occurred after $40 \mathrm{~h}$ at $70^{\circ} \mathrm{C}$, while $\mathrm{MOH} / \mathrm{V}_{2} \mathrm{O}_{5} / \mathrm{L}$-proline mixtures $(\mathrm{M}=\mathrm{Na}, \mathrm{K})$ gave a quantitative conversion to $\mathrm{P}^{2} \mathrm{C}^{-}$(Scheme 3B).

\section{Conclusions}

The interaction of vanadium ions with $\alpha$-amino acids has aroused a great interest due to possible biological implications, and vanadium(V) was found to exhibit a poor affinity towards these biologically relevant compounds. This aspect, combined with the peculiar reduction potential of $\mathrm{V}(\mathrm{V})$ species, allows to selectively achieve the unusual, one pot conversion of L-Proline to the corresponding $\alpha$-imino acidate, using $\mathrm{NH}_{4} \mathrm{VO}_{3}$ or $\mathrm{V}_{2} \mathrm{O}_{5}$ as oxidants in basic water medium. The best results, in terms of atom economy, yield and product stability, being obtained with $\mathrm{V}_{2} \mathrm{O}_{5}$. It is remarkable that the straightforward $\mathrm{V}(\mathrm{V})$ mediated oxidation of L-Proline is not reproducible with alternative chemical oxidants, including $\mathrm{H}_{2} \mathrm{O}_{2}$, leading to different outcomes (Scheme 6). Analogous amino acid to imino acid conversion was not observed by allowing a series of $\alpha$-amino acids to interact with $\mathrm{NH}_{4} \mathrm{VO}_{3} / \mathrm{NH}_{3}$. The unique properties associated to L-proline, among the family of $\alpha$-amino acid compounds, ${ }^{28}$ are probably responsible for the specific outcome observed. However, vanadium(V) oxyanions in basic aqueous solution were capable of reacting only with secondary $\alpha$-amino acids, primary and tertiary $\alpha$-amino acids resulting to be unreactive. It should be noted that most of the oxidizing agents employed in the classical Strecker degradation of $\alpha$-amino acids, either are effective towards primary amino acids only, or do not show any substrate selectivity.

Our results suggest the possible convenience in the use of simple and cost effective $\mathrm{V}(\mathrm{V})$ compounds as stoichiometric oxidative agents for exploring uncommon organic synthetic pathways.

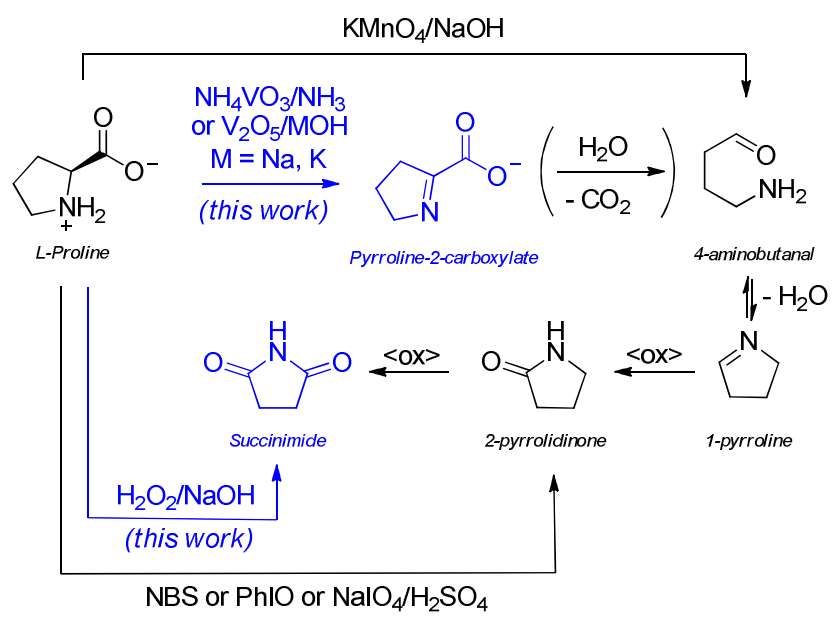

Scheme 6. Overview of oxidation reactions of L-proline.

\section{Experimental}

\section{a) General}

All manipulations were performed in air with common laboratory glassware. Reactions were carried out using deionised water. Solvents and reagents, including $\alpha$-amino acids, $\mathrm{NH}_{4} \mathrm{VO}_{3}(\geq 99 \%)$ and $\mathrm{V}_{2} \mathrm{O}_{5}(98 \%)$ were used as received from Sigma-Aldrich. An Orion pH-meter equipped with a Hamilton glass $\mathrm{pH}$-electrode was used for $\mathrm{pH}$ measurements. The instrument was routinely calibrated with standard $\mathrm{pH}=2.0,5.0$ and 11.0 buffer solutions (Carlo Erba). Infrared spectra $\left(4000-650 \mathrm{~cm}^{-1}\right)$ were recorded at $298 \mathrm{~K}$ on a FT IRPerkin Elmer Spectrometer, equipped with a UATR sampling accessory. Spectra in the $200-650 \mathrm{~cm}^{-1}$ region were recorded in the transmission mode on CsI tablets. UV-Vis measurements were carried out at $298 \mathrm{~K}$ on a GE Healthcare Ultrospec 2100 pro spectrophotometer, using $1 \mathrm{~mm}$ quartz cuvettes in the $200-800 \mathrm{~nm}$ range. NMR spectra were recorded at $293 \mathrm{~K}$ on a Bruker Avance II DRX400 instrument equipped with a BBFO broadband probe. The chemical shifts were referenced to the non-deuterated aliquot of the solvent ${ }^{1} \mathrm{H}$ and ${ }^{13} \mathrm{C}$ ) or to external standards $\left({ }^{51} \mathrm{~V}\right.$ to $\left.\mathrm{VOCl}_{3}\right)$. The ${ }^{1} \mathrm{H}$ and ${ }^{13} \mathrm{C}$ NMR spectra were assigned with the assistance of DEPT-135 and ${ }^{1} \mathrm{H}-{ }^{13} \mathrm{C}$ correlation experiments $\left(g s\right.$-HSQC and $g s$-HMBC). ${ }^{29}$ A sealed capillary tube with $\mathrm{C}_{6} \mathrm{D}_{6}$ was used when NMR analysis was performed on aliquots of the reaction mixture in a non-deuterated media. In this case, NMR yield was estimated from the relative intensity of ${ }^{13} \mathrm{C}$ signals of analogous carbon atoms in the $\alpha$-amino acid reactant and the product. Magnetic susceptibilities (reported per V atom) were measured on solid samples at $298 \mathrm{~K}$ with a Magway MSB Mk1 magnetic susceptibility balance (Sherwood Scientific Ltd). Diamagnetic corrections were introduced according to König. ${ }^{30}$ Melting points and decomposition temperatures were determined on a STMP3 Stuart scientific instrument with a capillary apparatus. Carbon, hydrogen, nitrogen analyses were performed on a Carlo Erba mod. 1106 instrument. The vanadium(IV) and vanadium(V) contents were determined according to the method proposed by Mittal and Mehrotra. $^{31}$

X-Ray powder diffraction analysis (XRPD) were performed by a Thermo ARL X'TRA powder diffractometer, operating in the Bragg-Brentano geometry and equipped with a $\mathrm{Cu}$-anode $\mathrm{X}$-ray source $\left(\mathrm{K}_{\alpha}, \lambda=1.5418 \AA\right.$ ), using a Peltier $\mathrm{Si}(\mathrm{Li})$ cooled solid state detector. The patterns were collected with a scan rate of $0.02 \%$ in the $5^{\circ}-90^{\circ} 2 \theta$ range. The phase identifications were performed with the PDF-4+ 2015 database provided by the International Centre for Diffraction Data (ICDD). Polycrystalline samples were ground in 
a mortar and then put in a low-background sample holder for the data collection.

\section{b) Reactions between $\mathrm{V}(\mathrm{V})$ ions $\left(\mathrm{NH}_{4} \mathrm{VO}_{3}\right.$ as precursor) and L-proline in aqueous ammonia solution.}

The determination of the optimum conditions for $\mathrm{pH}$ (as a function of the $\mathrm{NH}_{3} / \mathrm{V}$ molar ratio) and the analysis of vanadium species in solution through ${ }^{51} \mathrm{~V}$ NMR spectroscopy are given as Supporting information (Figures S3 and S4).

\section{i) Optimization of the reaction conditions.}

$\mathbf{N H}_{3} / \mathbf{V}$ molar ratio. A suspension of $\mathrm{NH}_{4} \mathrm{VO}_{3}(8.4 \mathrm{mmol})$ in $\mathrm{H}_{2} \mathrm{O}$ was treated with variable amounts of $\mathrm{NH}_{3}\left(\mathrm{NH}_{3} / \mathrm{V}\right.$ molar ratio $\left.=0.1,1.0,2.1\right)$ then with L-Proline $(2.1 \mathrm{mmol}, \mathrm{V} /$ Pro molar ratio $=4.0)$ and diluted with $\mathrm{H}_{2} \mathrm{O}$ (final volume of the solution: $10 \mathrm{~mL}$ ). Higher values of $\mathrm{pH}(12.2$, 14.3) were obtained as follows: $\mathrm{NH}_{4} \mathrm{VO}_{3}(8.4 \mathrm{mmol})$ was suspended in $\mathrm{H}_{2} \mathrm{O}$, treated with $\mathrm{NaOH}$ until complete dissolution of the solid $(\mathrm{pH}=14.3)$ and diluted with $\mathrm{H}_{2} \mathrm{O}$ (final volume of the solution: $10 \mathrm{~mL}$ ). The $\mathrm{pH}$ was adjusted to 12.2 by adding the appropriate amount of $37 \% \mathrm{HCl}$. The mixture was heated at $70^{\circ} \mathrm{C}$ with a reflux condenser for $40-65 \mathrm{~h}$. When a reaction took place, a black suspension was obtained within $1 \mathrm{~h}$ whose ${ }^{13} \mathrm{C}$ NMR spectrum showed the resonances of L-proline (unreacted starting material) and 1-pyrroline-2-carboxylate $(\mathrm{P} 2 \mathrm{C})$ anion $\left[{ }^{13} \mathrm{C}\left\{{ }^{1} \mathrm{H}\right\}: \delta=175.8\right.$ $(C=\mathrm{O}) ; 171.9(C=\mathrm{N}) ; 60.3\left(\mathrm{CH}_{2}-\mathrm{N}\right) ; 35.9\left(\mathrm{CH}_{2}-\mathrm{C}=\mathrm{N}\right) ; 22.0\left(\mathrm{CH}_{2}-\mathrm{CH}_{2}-\mathrm{CH}_{2}\right)$ ppm]. The highest NMR yield ( $40 \%$ after $45 \mathrm{~h}$ ) was obtained with $\mathrm{NH}_{3} / \mathrm{V}$ molar ratio $=1.0$; no reaction was observed with a $\mathrm{NH}_{3} / \mathrm{NH}_{4} \mathrm{VO}_{3}$ ratio of 0.1 and when the $\mathrm{pH}$ was adjusted to $\geq 12$ (see table S1, entries \#1-5).

Vanadium/L-Proline molar ratio. Reactions were performed with $\mathrm{NH}_{4} \mathrm{VO}_{3}(6.4 \mathrm{mmol}), 28 \% \mathrm{NH}_{3}\left(\mathrm{NH}_{3} / \mathrm{V}\right.$ molar ratio $\left.=1.0\right)$, variable amounts of L-Proline (V/Pro molar ratio $=1.0,2.0,4.0,8.0)$ and $\mathrm{H}_{2} \mathrm{O}$ (final volume of the solution: $4 \mathrm{~mL}$ ). The mixtures were heated at $70^{\circ} \mathrm{C}$ for $18-42$ $\mathrm{h}$ with a reflux condenser yielding black suspensions. The formation of P2 ${ }^{-}$was observed in all cases; the highest NMR yield of $\mathrm{P} 2 \mathrm{C}^{-}(60 \%$ after $31 \mathrm{~h}$ ) was obtained by using a Vanadium/L-proline molar ratio of 4 (see table S1, entries \#6-9).

Vanadium concentration. Reactions were performed with variable amounts of $\mathrm{NH}_{4} \mathrm{VO}_{3}(2.4,4.0,6.4,8.0 \mathrm{mmol}), 28 \% \mathrm{NH}_{3}\left(\mathrm{NH}_{3} / \mathrm{V}\right.$ molar ratio $=1.0)$, L-Proline $\left(\mathrm{V} /\right.$ Pro molar ratio $=4.0$ ) and $\mathrm{H}_{2} \mathrm{O}$ (final volume of the solution: $4 \mathrm{~mL}$ ). The mixtures were heated at $70^{\circ} \mathrm{C}$ with a reflux condenser for $25-45 \mathrm{~h}$ yielding black suspensions. Comparable NMR yields of $\mathrm{P}_{2} \mathrm{C}^{-}(50-60 \%$ after $20-30 \mathrm{~h})$ were obtained when the amount of $\mathrm{NH}_{4} \mathrm{VO}_{3}$ exceeded $1.0 \mathrm{~mol} \cdot \mathrm{L}^{-1}$ (see table $\mathrm{S} 1$, entries \#10-13), as expected for a saturated system. Therefore, we performed further reactions with a vanadium loading of $1.0 \mathrm{~mol} \cdot \mathrm{L}^{-1}$

Temperature and time. Reactions were performed with $\mathrm{NH}_{4} \mathrm{VO}_{3}$ (4.0 $\mathrm{mmol}), 28 \% \mathrm{NH}_{3}\left(\mathrm{NH}_{3} / \mathrm{V}\right.$ molar ratio $\left.=1.0\right)$, L-Proline $(\mathrm{V} /$ Pro molar ratio $=$ 4.0) and $\mathrm{H}_{2} \mathrm{O}$ (final volume of the solution: $4 \mathrm{~mL}$ ). The mixtures were heated at $70^{\circ} \mathrm{C}$ or $100^{\circ} \mathrm{C}$ with a reflux condenser yielding black suspensions. NMR analysis was performed at various times. The highest NMR yield $(60 \%)$ was reached when operating at $70^{\circ} \mathrm{C}$ for $46 \mathrm{~h}$ (see table $\mathrm{S} 1$, entries \#14-15). Formation of by-products and a lower $\mathrm{P}^{-} \mathrm{C}^{-}$yield $\left(40^{\circ} \mathrm{C}\right)$ were observed for a longer reaction time $(67 \mathrm{~h})$. No trace of $\mathrm{P} 2 \mathrm{C}^{-}$ was found working at $100^{\circ} \mathrm{C}$ even for shorter reaction times.

\section{ii) Isolation of products in the optimized conditions.}

The reaction was carried out with $\mathrm{NH}_{4} \mathrm{VO}_{3}(749 \mathrm{mg}, 6.4 \mathrm{mmol})$, L-Proline (184 mg, $1.6 \mathrm{mmol}), 28 \% \mathrm{NH}_{3}(0.45 \mathrm{~mL}, 6.5 \mathrm{mmol})$ and $\mathrm{H}_{2} \mathrm{O}(6.0 \mathrm{~mL})$. The mixture was heated at $70^{\circ} \mathrm{C}$ with a reflux condenser for $45 \mathrm{~h}$. Therefore, the black suspension was allowed to cool to room temperature and filtered. The black residue was washed with acetone and dried under vacuum. This solid was identified by XRPD analysis as a mixture of $\mathrm{NH}_{4} \mathrm{VO}_{3}$ and $\left(\mathrm{NH}_{4}\right)_{2} \mathrm{~V}_{3} \mathrm{O}_{8}\left(0.41 / 0.59\right.$ molar ratio, respectively) ${ }^{32}$ Yield: 626 $\mathrm{mg}, 90 \%$ with respect to the vanadium introduced. Anal. calcd. for $\left(\mathrm{NH}_{4} \mathrm{VO}_{3}\right)_{0.41}\left(\left(\mathrm{NH}_{4}\right)_{2} \mathrm{~V}_{3} \mathrm{O}_{8}\right)_{0.59}: \mathrm{H}, 2.73 ; \mathrm{N}, 9.48 ; \mathrm{V}(\mathrm{IV}), 8.89 ; \mathrm{V}(\mathrm{V}), 38.42$. Found: H, 2.68; N, 9.98; V(IV), 9.50; V(V), 38.0. IR (solid state): $v=$ $3210 \mathrm{~m}-\mathrm{br}, 3008 \mathrm{~m}-\mathrm{br}, 2814 \mathrm{~m}-\mathrm{br}, 1678 \mathrm{w}, 1652 \mathrm{w}, 1416 \mathrm{~s}, 1262 \mathrm{w}, 993 \mathrm{~m}$ $\left(\mathrm{V}^{\mathrm{IV}}=\mathrm{O}\right), 932 \mathrm{~s}, 809 \mathrm{~s}\left(\mathrm{~V}^{\mathrm{IV}}-\mathrm{O}-\mathrm{V}^{\mathrm{IV}}\right), 733 \mathrm{~s}\left(\mathrm{~V}^{\mathrm{V}}-\mathrm{O}-\mathrm{V}^{\mathrm{V}}\right), 524 \mathrm{w}, 502 \mathrm{w}, 426 \mathrm{~m}$ $365 \mathrm{~m}, 333 \mathrm{w}, 242 \mathrm{w} \mathrm{cm}{ }^{-1}$. Magnetic susceptivity: $\chi_{\mathrm{g}}=2.027 \times 10^{-6} \mathrm{~cm}^{3} \cdot \mathrm{g}^{-1}$; $\Sigma \chi_{\mathrm{m}}{ }^{\mathrm{D}}=-102.5 \times 10^{-6} \mathrm{~cm}^{3} \cdot \mathrm{mol}^{-1} ; \chi_{\mathrm{m}}{ }^{\mathrm{P}}=5.78 \times 10^{-4} \mathrm{~cm}^{3} \cdot \mathrm{mol}^{-1} ; \mu=1.16 \mu_{\mathrm{B}} \cdot{ }^{33}$ All attempts to isolate ammonium pyrroline-2-carboxylate from the filtrate solution were unsuccessful.

\section{c) Reactions between $\mathrm{V}(\mathrm{V})$ ions $\left(\mathrm{NH}_{4} \mathrm{VO}_{3}\right.$ as precursor) and $\alpha$-amino} acids in aqueous ammonia solution.

General procedure. A suspension of $\mathrm{NH}_{4} \mathrm{VO}_{3}(4.0 \mathrm{mmol})$ in $\mathrm{H}_{2} \mathrm{O}(3.7 \mathrm{~mL})$ was treated with $28 \% \mathrm{NH}_{3}\left(0.28 \mathrm{~mL}, \mathrm{NH}_{3} / \mathrm{V}\right.$ molar ratio $\left.=1.0\right)$ and with the selected $\alpha$-amino acid $(1.0 \mathrm{mmol}$, Vanadium/amino acid molar ratio $=4.0)$.
The mixture was heated at $70^{\circ} \mathrm{C}$ with a reflux condenser for $40 \mathrm{~h}$ and analyzed by ${ }^{13} \mathrm{C}\left\{{ }^{1} \mathrm{H}\right\}$ NMR spectroscopy.

i) $\alpha$-Amino acid = glycine, L-alanine, L-phenylalanine, $N, N$-dimethyl-Lphenylalanine, $\boldsymbol{N}, \boldsymbol{N}$-dimethylglycine. No reaction took place (colourless solution + colourless solid). The starting material is the only species identified in solution.

ii) $\alpha$-Amino acid = sarcosine, trans-4-hydroxy-L-proline. The mixture darkened. At the end of the reaction, the black suspension was allowed to cool at room temperature and filtered. The black residue was washed with acetone and dried under vacuum. This solid was identified as a mixture of $\mathrm{NH}_{4} \mathrm{VO}_{3}$ and $\left(\mathrm{NH}_{4}\right)_{2} \mathrm{~V}_{3} \mathrm{O}_{8}$, having identical IR spectrum with the product obtained with L-proline (section b/ii). Organic products were identified or isolated as follows.

Sarcosine. The unreacted $\alpha$-amino acid and $\mathrm{CH}_{3} \mathrm{NH}_{3}{ }^{+}\left({ }^{13} \mathrm{C}\left\{{ }^{1} \mathrm{H}\right\}: \delta=25.3\right.$ ppm, 65\% NMR yield) were identified in solution. A number of low intensity signals were observed, due to the extensive decomposition of the carboxymethyl fragment of sarcosine. ${ }^{13} \mathrm{C}\left\{{ }^{1} \mathrm{H}\right\}: \delta=179.3,177.0,173.4$, $171.1,167.9$, 166.4, 165.7, 164.0, 137.2, 65.5, 60.1, 58.6, 53.3, 43.4, 37.8, 35.4, $28.0 \mathrm{ppm}$.

Trans-4-hydroxy-L-proline. The $\mathrm{pH}$ of the filtrate solution was adjusted to 3 with $37 \% \mathrm{HCl}$. The aqueous phase was extracted with $\mathrm{Et}_{2} \mathrm{O}$. Pyrrole-2carboxylic acid was isolated as a colourless solid after solvent removal under vacuum. Yield: $90 \mathrm{mg}, 81 \%$. IR (solid state): $v=3351 \mathrm{~s}, 3124 \mathrm{w}-\mathrm{m}$, $3007 \mathrm{w}-\mathrm{m}-\mathrm{br}, 2918 \mathrm{w}-\mathrm{m}, 2850 \mathrm{w}-\mathrm{m}, 2700 \mathrm{w}-\mathrm{m}, 2753 \mathrm{w}-\mathrm{m}, 2624 \mathrm{w}-\mathrm{m}, 2574 \mathrm{w}-$ $\mathrm{m}, 2514 \mathrm{w}-\mathrm{m}, 2075 \mathrm{vw}, 1892 \mathrm{vw}-\mathrm{br}, 1654 \mathrm{~s}, 1553 \mathrm{~m}-\mathrm{s}, 1436 \mathrm{~s}, 1389 \mathrm{~m}-\mathrm{s}$, $1323 \mathrm{~s}, 1263 \mathrm{~m}, 1187 \mathrm{~s}, 1120 \mathrm{vs}, 1080 \mathrm{~m}, 1034 \mathrm{~s}, 947 \mathrm{~m}, 878 \mathrm{~s}, 845 \mathrm{~m}, 749 \mathrm{vs}$, $687 \mathrm{~m}-\mathrm{s} \mathrm{cm}{ }^{-1} .{ }^{1} \mathrm{H}$ NMR $\left(\mathrm{DMSO}-\mathrm{d}_{6}\right): \delta=11.54(\mathrm{~s}, 1 \mathrm{H}, \mathrm{COOH}) ; 6.95(\mathrm{dd}$ $1 \mathrm{H}, \mathrm{CH}-\mathrm{NH}) ; 6.73(\mathrm{dd}, 1 \mathrm{H}, \mathrm{CH}-\mathrm{C}-\mathrm{C}=\mathrm{O}) ; 6.14(\mathrm{dd}, 1 \mathrm{H}, \mathrm{CH}-\mathrm{CH}-\mathrm{CH}) \mathrm{ppm}$. ${ }^{13} \mathrm{C}\left\{{ }^{1} \mathrm{H}\right\}$ NMR $\left(\mathrm{DMSO}-\mathrm{d}_{6}\right): \delta=162.7(C=\mathrm{O}) ; 124.1(C \mathrm{H}-\mathrm{NH}) ; 123.1(C-$ $\mathrm{C}=\mathrm{O}) ; 115.5(\mathrm{CH}-\mathrm{C}-\mathrm{C}=\mathrm{O}) ; 110.0(\mathrm{CH}-\mathrm{CH}-\mathrm{CH}) \mathrm{ppm}$.

d) Reactions between $\mathrm{V}(\mathrm{V})$ ions $\left(\mathrm{NH}_{4} \mathrm{VO}_{3}\right.$ as precursor) and $\alpha$-amino acids in ammonia $\mathrm{D}_{2} \mathrm{O}$ solution.

The general procedure followed is identical to that described in section $\mathrm{c}$ except for the solvent $\left(\mathrm{D}_{2} \mathrm{O}\right)$. The Vanadium-containing solid isolated from these mixtures was identified as a mixture of $\mathrm{ND}_{4} \mathrm{VO}_{3}$ and $\left(\mathrm{ND}_{4}\right)_{2} \mathrm{~V}_{3} \mathrm{O}_{8}{ }^{34}$ IR (solid state): $v=3091 \mathrm{v}-\mathrm{w}-\mathrm{br}, 2348 \mathrm{~m}-\mathrm{w}-\mathrm{br}\left(\mathrm{ND}_{4}{ }^{+}\right), 2222 \mathrm{w}-\mathrm{br}, 2135 \mathrm{w}-\mathrm{sh}$, $2091 \mathrm{w}-\mathrm{sh}\left(\mathrm{ND}_{4}^{+}\right), 1401 \mathrm{vw}, 1115 \mathrm{vw}, 1073 \mathrm{~m}-\mathrm{w}\left(\mathrm{ND}_{4}^{+}\right), 983 \mathrm{~m}, 925 \mathrm{w}-\mathrm{m}$, $905 \mathrm{w}, 799 \mathrm{~s}, 726 \mathrm{~s} \mathrm{~cm}^{-1}$

i) $\alpha$-Amino acid $=$ L-proline. The unreacted $\alpha$-amino acid and 3,3dideutero-1-pyrroline-2-carboxylate $\operatorname{anion}^{26}\left(\mathrm{P} 2 \mathrm{C}-\mathrm{d}_{2} \overline{)}\right.$ were identified in solution. NMR yield: $35 \%$ after $30 \mathrm{~h} .{ }^{13} \mathrm{C}\left\{{ }^{1} \mathrm{H}\right\}$ NMR $\left(\mathrm{D}_{2} \mathrm{O}\right): \delta=175.7$ $(\mathrm{C}=\mathrm{O}), 171.9(\mathrm{C}=\mathrm{N}), 60.3\left(\mathrm{CH}_{2}-\mathrm{N}\right), 36.6-34.4\left(\mathrm{~m}, \mathrm{CD}_{2}\right), 21.7\left(\mathrm{CH}_{2} \mathrm{CD}_{2}\right)$ ppm.

ii) $\alpha$-Amino acid $=$ sarcosine. The unreacted $\alpha$-amino acid and $\mathrm{CH}_{3} \mathrm{ND}_{3}{ }^{+}$ were identified in solution. NMR yield: $35 \%$ after $76 \mathrm{~h}$.

${ }^{1} \mathrm{H}$ NMR $\left(\mathrm{D}_{2} \mathrm{O}\right): \delta=2.5(\mathrm{~s}) \mathrm{ppm} .{ }^{13} \mathrm{C}\left\{{ }^{1} \mathrm{H}\right\}$ NMR $\left(\mathrm{D}_{2} \mathrm{O}\right): \delta=24.3 \mathrm{ppm}$.

iii) $\alpha$-Amino acid = trans-4-hydroxy-L-proline. Non-deuterated pyrrole-2carboxylic acid was isolated as a colourless solid. Yield: $91 \mathrm{mg}, 82 \%$ (reaction time $63 \mathrm{~h}$ ).

e) Reactions between $\mathrm{V}(\mathrm{V})$ ions $\left(\mathrm{V}_{2} \mathrm{O}_{5}\right.$ as precursor) and L-Proline in basic aqueous solution.

General procedure. A suspension of $\mathrm{V}_{2} \mathrm{O}_{5}(10 \mathrm{mmol})$ in $\mathrm{H}_{2} \mathrm{O}(20 \mathrm{~mL})$ was treated with L-proline $(5.0 \mathrm{mmol}, \mathrm{V} /$ Pro molar ratio $=4)$ and the selected base until $\mathrm{pH}=10$. The brown-green suspension was heated at a specified temperature and analyzed by ${ }^{13} \mathrm{C}\left\{{ }^{1} \mathrm{H}\right\}$ NMR spectroscopy. Products were identified or isolated as follows.

i) $\mathrm{NaOH}$ as base. A dark suspension was obtained after $67 \mathrm{~h}$ at $100^{\circ} \mathrm{C}$ with quantitative formation of $\mathrm{P} 2 \mathrm{C}^{-}\left({ }^{13} \mathrm{C} \mathrm{NMR}\right.$ analysis). The reaction mixture was allowed to cool to room temperature and filtered. The solid was recovered by filtration, washed with water and dried in vacuo affording black $\mathrm{NaV}_{2} \mathrm{O}_{5}$. The brown filtrate was added of acetone which caused the precipitation of a pale brown solid $\left(\mathrm{NaVO}_{3}\right)$ which was recovered by filtration and dried in vacuo. The yellow filtrate solution was dried in vacuo and the residue was re-dissolved in few $\mathrm{mL}$ of ethanol. $\mathrm{Et}_{2} \mathrm{O}$ addition caused the precipitation of sodium pyrroline-2-carboxylate, $\mathrm{Na}(\mathrm{P} 2 \mathrm{C})$, as an ivory solid. The product was isolated by filtration, dried under vacuum and stored under $\mathrm{N}_{2}$.

$\mathrm{NaV}_{2} \mathrm{O}_{5}$. Identified by XRDP analysis and IR spectroscopy. Yield: 1,36 g, $66 \%$ with respect to the vanadium introduced. IR (solid state): $v=1607 \mathrm{~W}$, $1412 \mathrm{w}, 1301 \mathrm{vw}, 992 \mathrm{~m}, 963 \mathrm{~m}, 916 \mathrm{w}-\mathrm{m}, 875 \mathrm{w}-\mathrm{m} \mathrm{cm}^{-1}$.

$\mathrm{NaVO}_{3}$. Identified by XRDP analysis and IR spectroscopy. ${ }^{35}$ Yield: $750 \mathrm{mg}$, $31 \%$ with respect to the vanadium introduced. IR (solid state): $v=1599 \mathrm{w}$, 1416w, 960w-m, 929w-m, 869vs cm ${ }^{-1}$. 
$\mathrm{Na}(\mathrm{P} 2 \mathrm{C})$. Yield: $54 \mathrm{mg}, 8 \%$. Melting point: $255^{\circ} \mathrm{C}$ (decomposition). IR (solid state): $v=2951 \mathrm{w}, 2926 \mathrm{w}, 2867 \mathrm{w}, 1663 \mathrm{vw}, 1638 \mathrm{w}, 1606 \mathrm{~m}-\mathrm{s}\left(\mathrm{COO}^{-}\right)$, $1448 \mathrm{w}, 1409 \mathrm{~m}\left(\mathrm{COO}^{-}\right), 1300 \mathrm{~m}, 1257 \mathrm{w}-\mathrm{m}, 1208 \mathrm{w}, 1155 \mathrm{vw}, 1134 \mathrm{w}-\mathrm{m}$, $1043 \mathrm{w}, 1009 \mathrm{w}, 988 \mathrm{w}-\mathrm{m}, 915 \mathrm{vw}, 885 \mathrm{vw}, 780 \mathrm{~m}, 723 \mathrm{w}-\mathrm{sh} \mathrm{cm}{ }^{-1} .{ }^{1} \mathrm{H}$ NMR $\left(\mathrm{D}_{2} \mathrm{O}\right) \delta=3.77\left(\mathrm{~m}, 2 \mathrm{H}, \mathrm{CH}_{2}-\mathrm{N}\right) ; 2.66\left(\mathrm{~m}, 1.5 \mathrm{H}, \mathrm{CH}_{2}-\mathrm{C}=\mathrm{N}\right)^{36} ; 1.85(\mathrm{~m}, 2 \mathrm{H}$ $\left.\mathrm{CH}_{2}-\mathrm{CH}_{2}-\mathrm{CH}_{2}\right)$ ppm. ${ }^{13} \mathrm{C}\left\{{ }^{1} \mathrm{H}\right\} \operatorname{NMR}\left(\mathrm{D}_{2} \mathrm{O}\right) \delta=176.8(\mathrm{C}=\mathrm{O}) ; 171.9(\mathrm{C}=\mathrm{N})$ $60.3\left(\mathrm{CH}_{2}-\mathrm{N}\right) ; 35.9\left(\mathrm{CH}_{2}-\mathrm{C}=\mathrm{N}\right) ; 22.0\left(\mathrm{CH}_{2}-\mathrm{CH}_{2}-\mathrm{CH}_{2}\right)$ ppm. UV-Vis $\left(\mathrm{H}_{2} \mathrm{O}\right)$ : $\lambda_{\max }\left(\varepsilon / \mathrm{L} \cdot \mathrm{cm}^{-1} \cdot \mathrm{mol}^{-1}\right)=205\left(1.8 \cdot 10^{3}\right), 252\left(3.6 \cdot 10^{2}\right), 307(9.1 \cdot 10) \mathrm{nm}$.

ii) $\mathrm{KOH}$ as base. A dark suspension was obtained after $90 \mathrm{~h}$ at $100^{\circ} \mathrm{C}$ with quantitative formation of $\mathrm{P} 2 \mathrm{C}^{-}\left({ }^{13} \mathrm{C}\right.$ NMR analysis; 75\% NMR yield after $67 \mathrm{~h}$ ). From this reaction mixture, $\mathrm{K}_{2} \mathrm{~V}_{3} \mathrm{O}_{8}, \mathrm{KVO}_{3}$ and potassium pyrroline2-carboxylate, $\mathrm{K}(\mathrm{P} 2 \mathrm{C})$, were isolated as described in section e-i.

$K_{2} V_{3} O_{8}$. Yield: $1.50 \mathrm{~g}, 62.5 \%$ with respect to the vanadium introduced. IR (solid state): $v=977 \mathrm{~m}, 936 \mathrm{~m}, 926 \mathrm{~m}, 811 \mathrm{~s}, 734 \mathrm{~s} \mathrm{~cm}^{-1}$.

$\mathrm{KVO}_{3}$. Identified by XRPD and IR analysis. ${ }^{37}$ Yield: $903 \mathrm{mg}, 32.7 \%$ with respect to the vanadium introduced. IR (solid state): $v=3247 \mathrm{vw}-\mathrm{br}, 1593 \mathrm{w}$ 1393w, 1320w-sh, 963w-m, 912m, 894w-m, 846w-m, 760w-br, 666vw cm

$K(P 2 C)$. Yield: $226 \mathrm{mg}, 35 \%$. Hygroscopic solid. ${ }^{1} \mathrm{H}$ and ${ }^{13} \mathrm{C}$ spectra in $\mathrm{D}_{2} \mathrm{O}$ are identical to the sodium salt.

iii) $\mathbf{N E t}_{3}$ as base. A yellow solution was obtained after $40 \mathrm{~h}$ at $70^{\circ} \mathrm{C}$ Unreacted L-Proline was the only species identified in solution.

\section{f) Reactions between $\mathrm{H}_{2} \mathrm{O}_{2}$ and L-Proline in aqueous solution.}

A solution of L-proline $(5 \mathrm{mmol})$ in $\mathrm{H}_{2} \mathrm{O}(15 \mathrm{~mL})$ was treated with $30 \%$ $\mathrm{H}_{2} \mathrm{O}_{2}(5 \mathrm{~mL}, 50 \mathrm{mmol})$ and then with $\mathrm{NaOH}$ until $\mathrm{pH}=10$. The resulting colourless solution was refluxed for $50 \mathrm{~h}$ then allowed to cool to room temperature. The aqueous solution was extracted with $\mathrm{Et}_{2} \mathrm{O}$ and the organic phase was dried in vacuum. The residue was identified as a mixture of succinimide $(81 \%)$ and succinic anhydride $(19 \%)$ by NMR analysis. IR (solid state): $v=2934 \mathrm{w}-\mathrm{m}, 2533 \mathrm{w}, 2251 \mathrm{w}-\mathrm{m}, 2087 \mathrm{w}-\mathrm{m}, 1771 \mathrm{w}, 1682 \mathrm{vs}$ $1555 \mathrm{~m}, 1417 \mathrm{~m}-\mathrm{s}, 1379 \mathrm{~s}, 1344 \mathrm{~s}, 1298 \mathrm{~m}-\mathrm{s}, 1264 \mathrm{~m}, 1198 \mathrm{~s}, 1177 \mathrm{~m}-\mathrm{s}, 1093 \mathrm{w}-$ $\mathrm{m}, 1046 \mathrm{~m}-\mathrm{s}, 890 \mathrm{~m}, 802 \mathrm{~m}-\mathrm{s}, 677 \mathrm{w}-\mathrm{m} \mathrm{cm}^{-1}$. ${ }^{1} \mathrm{H}$ NMR $\left(\mathrm{D}_{2} \mathrm{O}\right): \delta=2.71(\mathrm{~s}, 4 \mathrm{H}$ $\mathrm{CH}_{2}$, succinic anhydride); $2.58\left(\mathrm{~s}, 4 \mathrm{H}, \mathrm{CH}_{2}\right.$, succinimide) ppm. ${ }^{13} \mathrm{C}\left\{{ }^{1} \mathrm{H}\right\}$ NMR $\left(\mathrm{D}_{2} \mathrm{O}\right.$ ): $\delta=183.2$ (succinimide, $C=\mathrm{O}$ ); 177.5 (succinic anhydride, $\mathrm{C}=\mathrm{O}$ ); 29.5 (succinimide, $\mathrm{CH}_{2}$ ); 29.2 (succinic anhydride, $\mathrm{CH}_{2}$ ) ppm.

\section{Computational Details}

The computational geometry optimizations were carried out without symmetry constrains, using the range-separated DFT functional $\omega \mathrm{B} 97 \mathrm{X},{ }^{38}$ in combination with the split-valence polarized basis set of Ahlrichs and Weigend. ${ }^{39}$ The "unrestricted" formalism was applied for compounds with unpaired electrons, and the lack of spin contamination was verified by comparing the final $\left\langle\mathrm{S}^{2}\right\rangle$ values with the theoretical ones. The stationary points were characterized by IR simulations (harmonic approximation), from which zero-point vibrational energies and thermal corrections $(\mathrm{T}=$ 298.15 K and $343.15 \mathrm{~K}$ ) were obtained. ${ }^{40}$ The C-PCM implicit solvation model was added to $\omega \mathrm{B} 97 \mathrm{X}$ calculations, considering water as continuous medium. ${ }^{41}$ The software used was Gaussian '09. ${ }^{42}$ Preliminary DFT calculations were carried out in vacuo with the EDF2 ${ }^{43}$ hybrid-GGA functional and the $6-31 \mathrm{G}^{* *}$ basis set, ${ }^{44}$ using the Spartan '16 software. ${ }^{45}$ package.

\section{Supporting Information}

Detailed description of the determination of $\mathrm{pH}$ as a function of the $\mathrm{NH}_{3} / \mathrm{V}$ molar ratio, Figures S1-S6 and Table S1.

\section{Acknowledgements}

The University of Pisa is gratefully acknowledged for financial support

\section{References and Notes}

\$ E-mail: fabio.marchetti1974@unipi.it

1 (a) X.-H. Cai and B. Xie, ARKIVOK, 2014, 205-248; (b) J. Martens, ChemCatChem, 2010, 2, 379-381; (c) G. Szöllösi, I. Kun andM.
Bartók, Chirality, 2001, 13, 619-624; (d) L. Yet, Angew. Chem. Int. Ed., 2001, 40, 875-877.

2 a) G. P. Rizzi, Food Rev. Int., 2008, 24, 416-435; b) V. A. Yaylayan, Food Sci. Technol. Res., 2003, 9, 1-6.

3 T. Inokuma, T. Jichu, K. Nishida, A. Shigenaga and A. Otaka, Chem. Pharm. Bull., 2017, 65, 573-581. (b) L. Pollegioni, P. Motta and G. Molla, Appl Microbiol Biotechnol., 2013, 97, 9323-9341. (c) D. H. L Barton and F. Taran, Tetrahedron Lett., 1998, 39, 4777-4780.

4 M. L. Lewis, S. L. Martin, C. J. Rowe, J. D. Sutherland, E. J. Wilson and M. C. Wright, Bioorg. Med. Chem. Lett., 1993, 3, 1197-1202.

5 J. Häusler and U. Schmidt, Liebigs Ann. Chem., 1979, 1881-1889.

6 (a) R. Srinivasan, R. T. Medary, H. F. Fisher, D. J. Norris and R. Stewar, J. Am. Chem. Soc,. 1982, 104, 807-812. (b) K. Hasse and A. Wieland, Chem. Ber., 1960, 1686-1692.

7 C. Klein, G. Schulz and W. Steglich, Liebigs Ann. Chem., 1983, 1623-1637.

8 (a) D. Wellner and H. Scannone, Biochemistry, 1964, 3, 1746-1749; (b) C.-M. Ling and L. R. Hedrick, J. Bacteriol., 1964, 87, 14621470 .

9 A. E. M. Abdel-Hady, Ind. Engl. Chem. Res., 2011, 50, 1242112425 .

10 M. Ochiai, M. Inenaga, Y. Nagao, R. M. Moriarty, R. K. Vaid and M. P. Duncan, Tetrahedron Lett., 1988, 29, 6917-6920.

11 P. D. Bragg and L. Hough, J. Chem. Soc., 1958, 4050-4053

12 (a) R. T. Mahesh, M. B. Bellakki and S.T. Nandibewoor, J. Chem. Res., 2005, 13-17; (b) V. C. Seregar, C. V. Hiremath and S. T. Nandibewoor, Transition Met. Chem., 2006, 31, 541-548; (c) R. Tripathi and S. K. Upadhyay, J. Korean Chem. Soc., 2014, 58, 351 358 .

13 L. Macholán and J. Vencálková, Chem. Ber., 1963, 96, 237-246.

14 (a) M. Yamaguchi, K. Machiguchi, T. Mori, K. Kikuchi, I. Ikemoto and T. Yamagishi, Inorg. Chem., 1996, 35, 143-148; (b) M. Yamaguchi, M. Saburi, S. Yoshikawa and T. Yamagishi, Bull. Chem. Soc. Jpn., 1994, 67, 1341-1347; (c) A. Hammershøi, R. M. Hartshorn and A. M. Sargeson, Inorg. Chem. 1990, 29, 4525-4530; (d) M. Yamaguchi and T. Yamagishi, Inorg Chem., 1993, 32, 2981-2982; (e) B. Wagner, U. Taubald and W. Beck, Chem. Ber., 1989, 122, 1031-1034;

15 (a) A. Ścibior, Chem. Biol. Interact., 2016, 258, 214-233; (b) R Imtiaz, M. S. Rizwan, S. Xiong, H. Li, M. Ashraf, S. M. Shahzad, M. Rizwan and S. Tu, Environ. Int., 2015, 80, 79-88.

16 (a) D. C. Crans, H. Hoist, A. D. Keramidas and D. Rehder, Inorg. Chem., 1995, 34, 2524-2534 (b) V. Vergopoulos, W. Priebsch, M. Fritzsche and D. Rehder, Inorg. Chem. 1993, 32, 1844-1849; (c) D Rehder, Inorg. Chem., 1988, 27, 4312-4316.

17 (a) G. Maciejewska, M. Nosek, T. Glowiak, J. Starosta and M. Ciaslak-Golonka, Polyhedron 2003, 22, 1415-1423; (b) M. K. Chaudhuri, S. K. Chettri, P. C. Paul, P. Srinivas, J. Fluorine Chem., 1996, 78, 131-135 and references therein.

18 C. Gabriel, M. Kaliva, J. Venetis and P. Baran, I. RodriguezEscudero, G. Voyiatzis, M. Zervou and A. Salifoglou, Inorg. Chem., 2009, 48, 476-487.

19 (a) G. Arrambidey, D. Gambino and E. J. Baran, J. Coord Chem., 2009, 62, 63-74; (b) A. D. Keramidas, S. M. Miller, O. P. Anderson and D. C. Crans, J. Am. Chem. Soc., 1997, 119, 8901-8915.

20 S. Çakir and E. Biçer, J. Chil. Chem. Soc., 2010, 55, 236-239.

21 (a) CRC Handbook of Chemistry and Physics, D. R. Lide, Ed., 82th Ed. CRC Press, Boca Raton, FL, 2001; (b) J.-H. Huang, F. Huang, L. Evans and S. Glasauer, Chem. Geol., 2015, 417, 68-69.

22 (a) J. Krakowiak, D. Lundberg and I. Persson, Inorg. Chem., 2012, 51, 9598-9609; (b) D. Rehder, Bioinorganic Vanadium Chemistry Wiley, 2008.

23 A. Meetsma, J. L. de Boer, A. Damascelli, J. Jegoudez, A. Revcolevschi and T. T. M. Palstra, Acta Cryst., Section C, 1998, 54, 1558-1561.

$24\left[\mathrm{~V}_{4} \mathrm{O}_{12}\right]^{4-}+\mathrm{H}_{2} \mathrm{O} \rightarrow\left[\mathrm{V}_{4} \mathrm{O}_{11}(\mathrm{OH})\right]^{3-}+\mathrm{OH}^{-}, \Delta \mathrm{G}=-120.6 \mathrm{kcal} \mathrm{mol}^{-1}$; $\left[\mathrm{V}_{4} \mathrm{O}_{11}(\mathrm{OH})\right]^{3-}+\mathrm{H}_{2} \mathrm{O} \rightarrow\left[\mathrm{V}_{4} \mathrm{O}_{10}(\mathrm{OH})_{2}\right]^{2-}+\mathrm{OH}^{-}, \Delta \mathrm{G}=-25.6 \mathrm{kcal}$ $\mathrm{mol}^{-1} ;\left[\mathrm{V}_{4} \mathrm{O}_{10}(\mathrm{OH})_{2}\right]^{2-} \mathrm{H}_{2} \mathrm{O} \rightarrow\left[\mathrm{V}_{4} \mathrm{O}_{9}(\mathrm{OH})_{3}\right]^{-}+\mathrm{OH}^{-}, \Delta \mathrm{G}=44.4 \mathrm{kcal}$ $\mathrm{mol}^{-1}$. DFT EDF2 calculations.

25 A. N. Radhakrishnan and A. Meister, J. Biol. Chem., 1957, 226, 559571.

26 J. Häusler and H. Kählig, Monatsh. Chem., 2005, 136, 719-726.

27 (a) K. Severin, R. Bergs and W. Beck, Angew. Chem. Int. Ed., 1998, 37, 1634-1654; (b) W. Beck, Z. Naturforsch., 2009, 64b, 1221-1245. 
(a) G. Berger, M. Vilchis-Reyes and S. Hanessian, Angew. Chem Int. Ed., 2015, 54, 13268-13272; (b) J. Paradowska, M. Stodulski and J. Mlynarski, Angew. Chem. Int. Ed., 2009, 48, 4288-4297; (c) F. Marchetti, G. Pampaloni and S. Zacchini, RSC Adv., 2014, 4, 6087860882.

29 W. Willker, D. Leibfritz, R. Kerssebaum, and W. Bermel, Magn. Reson. Chem., 1993, 31, 287-292.

30 E. König, Magnetische Eigenschaften der Koordinations und Metallorganischen Verbindungen der Übergangselemente in Landolt-Börnstein, Zahlenwerte und Funktionen aus Naturwissenschaften und Technik, Springer-Verlag, Berlin, Göttingen, Heidelberg, 6th edn, 1966, 2, p. 16.

31 R. K. Mittal and R. C. Mehrotra, Fresenius' Z. Anal. Chem. 1965 , 209, 405-409. $\mathrm{KMnO}_{4}$ and $\left(\mathrm{NH}_{4}\right)_{2} \mathrm{Fe}\left(\mathrm{SO}_{4}\right)_{2} \cdot 6 \mathrm{H}_{2} \mathrm{O}$ (Mohr's salt) solutions were previously standardized with $\mathrm{Na}_{2} \mathrm{C}_{2} \mathrm{O}_{4}$ and $\mathrm{KMnO}_{4}$ solutions, respectively. A weighted amount of sample was dissolved in $6 \mathrm{M} \mathrm{H}_{2} \mathrm{SO}_{4}$. The vanadium(IV) content was determined with $\mathrm{KMnO}_{4}$ titration, the total amount of vanadium was then determined with a back titration with Mohr's salt solution. Vanadium(V) content was then obtained by difference.

32 T.-Z. Ren, Z.-Y. Yuan and X. Zou, Cryst. Res. Technol., 2007, 42, 317-320.

33 The magnetic moment in $\left(\mathrm{NH}_{4}\right)_{2} \mathrm{~V}_{3} \mathrm{O}_{8}$ is lower than expected for a $\mathrm{d}^{1}$ ion $(\mu=1.70 \mu \mathrm{B})$ due to V(IV)-V(IV) interactions. F. R. Theobald, J.-G. Theobald, J. C. Vedrine, R. Clad and J. Renard, J. Phys. Chem. Sol., 1984, 45, 581-587.

34 A. M. Heyns, M. W. Venter and K. J. Range, Z. Naturforsch., 1987, 42b, 843-852.

35 D. de Waal and A. M. Heyns, Mat. Res. Bull., 1992, 27, 129-136.

36 Slow deuteration of $\mathrm{C} 3$ is observed at room temperature in $\mathrm{D}_{2} \mathrm{O}$ solution thus lowering the value of the integral at $2.66 \mathrm{ppm}$.

37 N. K. Misra, R. N. P. Choudhary and K. L. Yadav, Pramana, 1995, 44, 219-224.

38 (a) Yu. Minenkov, Å. Singstad, G. Occhipinti and V. R. Jensen Dalton Trans., 2012, 41, 5526-5541; (b) J.-D. Chai and M. HeadGordon, Phys. Chem. Chem. Phys., 2008, 10, 6615-6620; (c) I. C. Gerber and J. G. Ángyán, Chem. Phys. Lett., 2005, 415, 100-105.

39 F. Weigend and R. Ahlrichs, Phys. Chem. Chem. Phys., 2005, 7, 3297-3305.

40 C. J. Cramer, Essentials of Computational Chemistry, 2nd Edition, Wiley, Chichester, 2004.

41 (a) V. Barone and M. Cossi, J. Phys. Chem. A, 1998, 102, 1995 2001; (b) M. Cossi, N. Rega, G. Scalmani and V. Barone, J. Comput. Chem., 2003, 24, 669-681.

42 Gaussian 09, Revision C.01, M. J. Frisch, G. W. Trucks, H. B. Schlegel, G. E. Scuseria, M. A. Robb, J. R. Cheeseman, G. Scalmani, V. Barone, B. Mennucci, G. A. Petersson, H. Nakatsuji, M. Caricato, X. Li, H. P. Hratchian, A. F. Izmaylov, J. Bloino, G. Zheng, J. L. Sonnenberg, M. Hada, M. Ehara, K. Toyota, R. Fukuda, J. Hasegawa, M. Ishida, T. Nakajima, Y. Honda, O. Kitao, H. Nakai, T. Vreven, J. A. Montgomery Jr., J. E. Peralta, F. Ogliaro, M. Bearpark, J. J. Heyd, E. Brothers, K. N. Kudin, V. N. Staroverov, R. Kobayashi, J. Normand, K. Raghavachari, A. Rendell, J. C. Burant, S. S. Iyengar, J. Tomasi, M. Cossi, N. Rega, J. M. Millam, M. Klene, J. E. Knox, J. B. Cross, V. Bakken, C. Adamo, J. Jaramillo, R. Gomperts, R. E. Stratmann, O. Yazyev, A. J. Austin, R. Cammi, C. Pomelli, J. W. Ochterski, R. L. Martin, K. Morokuma, V. G Zakrzewski, G. A. Voth, P. Salvador, J. J. Dannenberg, S. Dapprich, A. D. Daniels, Ö. Farkas, J. B. Foresman, J. V. Ortiz, J. Cioslowski and D. J. Fox, Gaussian, Inc., Wallingford CT, 2010.

43 C. Y. Lin, M. W. George and P. M. W. Gill, Aust. J. Chem., 2004, 57, 365-370.

44 (a) W. J. Henre, R. Ditchfield and J. A. Pople, J. Chem. Phys., 1972, 56, 2257-2261. (b) V. Rassolov, J. A. Pople, M. Ratner and T.L. Windus, J. Chem. Phys., 1998, 109, 1223-1229.

45 (a) Spartan '16, Build 1.1.0, Wavefunction Inc., Irvine CA, USA 2016. (b) Y. Shao, Z. Gan, E. Epifanovsky, A. T. B. Gilbert, M. Wormit, J. Kussmann, A. W. Lange, A. Behn, J. Deng, X. Feng, D Ghosh, M. Goldey, P. R. Horn, L. D. Jacobson, I. Kaliman, R. Z. Khaliullin, T. Kuś, A. Landau, J. Liu, E. I. Proynov, Y. M. Rhee, R. M. Richard, M. A. Rohrdanz, R. P. Steele, E. J. Sundstrom, H. L. Woodcock III, P. M. Zimmerman, D. Zuev, B. Albrecht, E. Alguire, B. Austin, G. J. O. Beran, Y. A. Bernard, E. Berquist, K. Brandhorst, K. B. Bravaya, S. T. Brown, D. Casanova, C.-M. Chang, Y. Chen, S H. Chien, K. D. Closser, D. L. Crittenden, M. Diedenhofen, R. A.
DiStasio Jr., H. Do, A. D. Dutoi, R. G. Edgar, S. Fatehi, L. FustiMolnar, A. Ghysels, A. Golubeva-Zadorozhnaya, J. Gomes, M. W D. Hanson-Heine, P. H. P. Harbach, A. W. Hauser, E. G. Hohenstein, Z. C. Holden, T.-C. Jagau, H. Ji, B. Kaduk, K. Khistyaev, J. Kim, J. Kim, R. A. King, P. Klunzinger, D. Kosenkov, T. Kowalczyk, C. M. Krauter, K. U. Lao, A. D. Laurent, K. V. Lawler, S. V. Levchenko, C. Y. Lin, F. Liu, E. Livshits, R. C. Lochan, A. Luenser, P. Manohar, S. F. Manzer, S.-P. Mao, N. Mardirossian, A. V. Marenich, S. A. Maurer, N. J. Mayhall, E Neuscamman, C. Melania Oana, R. Olivares-Amaya, D. P. O’Neill, J. A. Parkhill, T. M. Perrine, R. Peverati, A. Prociuk, D. R. Rehn, E. Rosta, N. J. Russ, S. M. Sharada, S. Sharma, D. W. Small, A. Sodt, T. Stein, D. Stück, Y.-C. Su, A. J. W. Thom, T. Tsuchimochi, V. Vanovschi, L. Vogt, O. Vydrov, T. Wang, M. A. Watson, J. Wenzel A. White, C. F. Williams, J. Yang, S. Yeganeh, S. R. Yost, Z.-Q. You, I. Y. Zhang, X. Zhang, Y. Zhao, B. R. Brooks, G. K. L. Chan, D. M. Chipman, C. J. Cramer, W. A. Goddard III, M. S. Gordon, W. J. Hehre, A. Klamt, H. F. Schaefer III, M. W. Schmidt, C. David Sherrill, D. G. Truhlar, A. Warshel, X. Xu, A. Aspuru-Guzik, R. Baer, A. T. Bell, N. A. Besley, J.-D. Chai, A. Dreuw, B. D. Dunietz, T. R. Furlani, S. R. Gwaltney, C.-P. Hsu, Y. Jung, J. Kong, D. S. Lambrecht, W. Liang, C. Ochsenfeld, V. A. Rassolov, L. V. Slipchenko, J. E. Subotnik, T. Van Voorhis, J. M. Herbert, A. I. Krylov, P. M. W. Gill and M. Head-Gordon, Mol. Phys., 2015, 113, 184-215. 


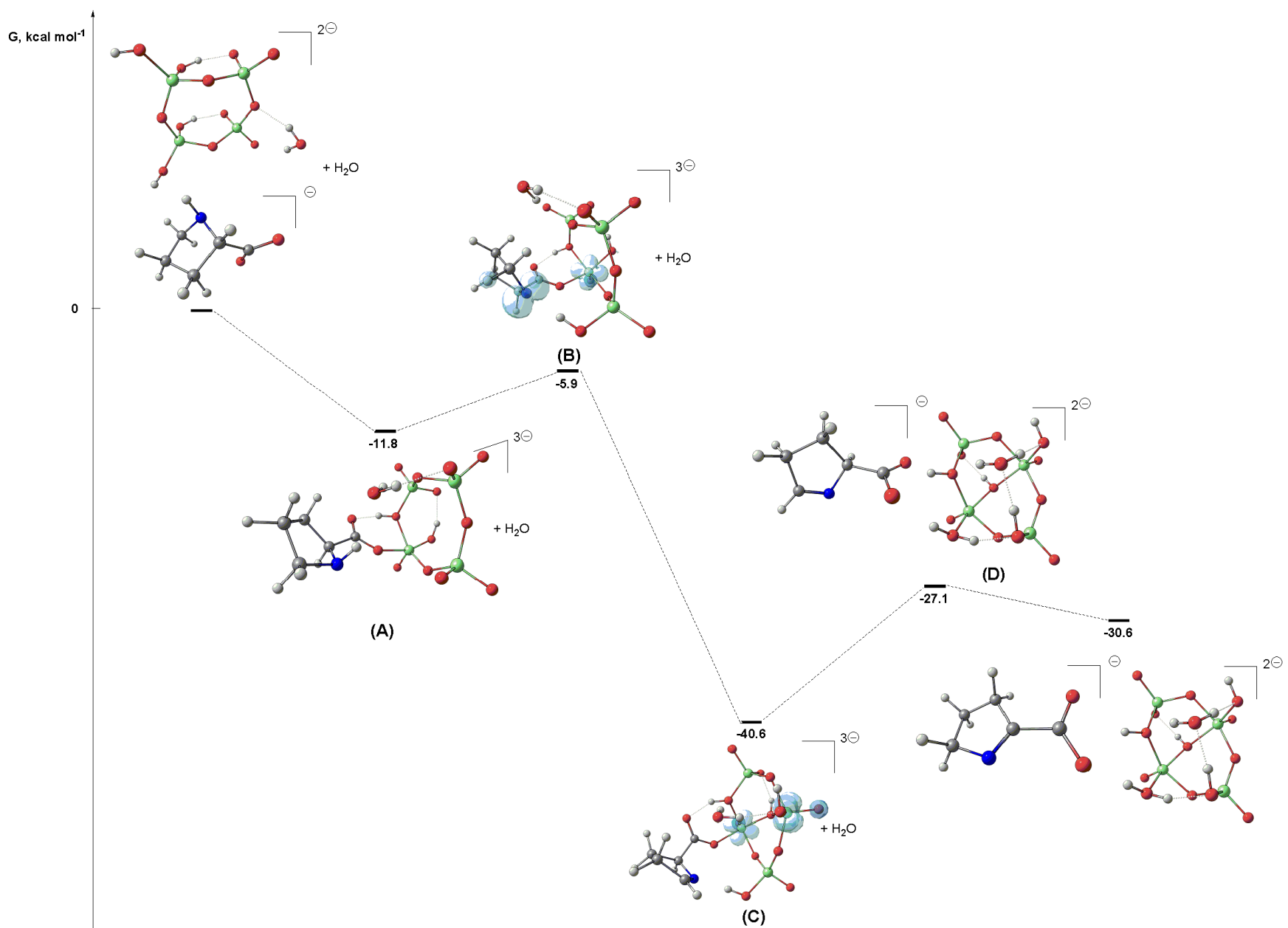

Figure 2. DFT-optimized structures of possible intermediates involved in the oxidation of L-prolinate to pirrolidine-2-carboxylate and relative Gibbs energy values $\left(\mathrm{kcal} \mathrm{mol}^{-1}, \mathrm{~T}=343.15 \mathrm{~K}\right) . \mathrm{C}-\mathrm{PCM} / \omega \mathrm{B} 97 \mathrm{X}$ calculations, water as continuous medium. Colour map: light grey, hydrogen; dark grey, carbon; red, oxygen; blue, nitrogen; green, vanadium, light blue, spin density surface (isovalue $=0.01$ a.u.). Cartesian coordinates of the DFT-optimized structures are collected in a separated. xyz file. 


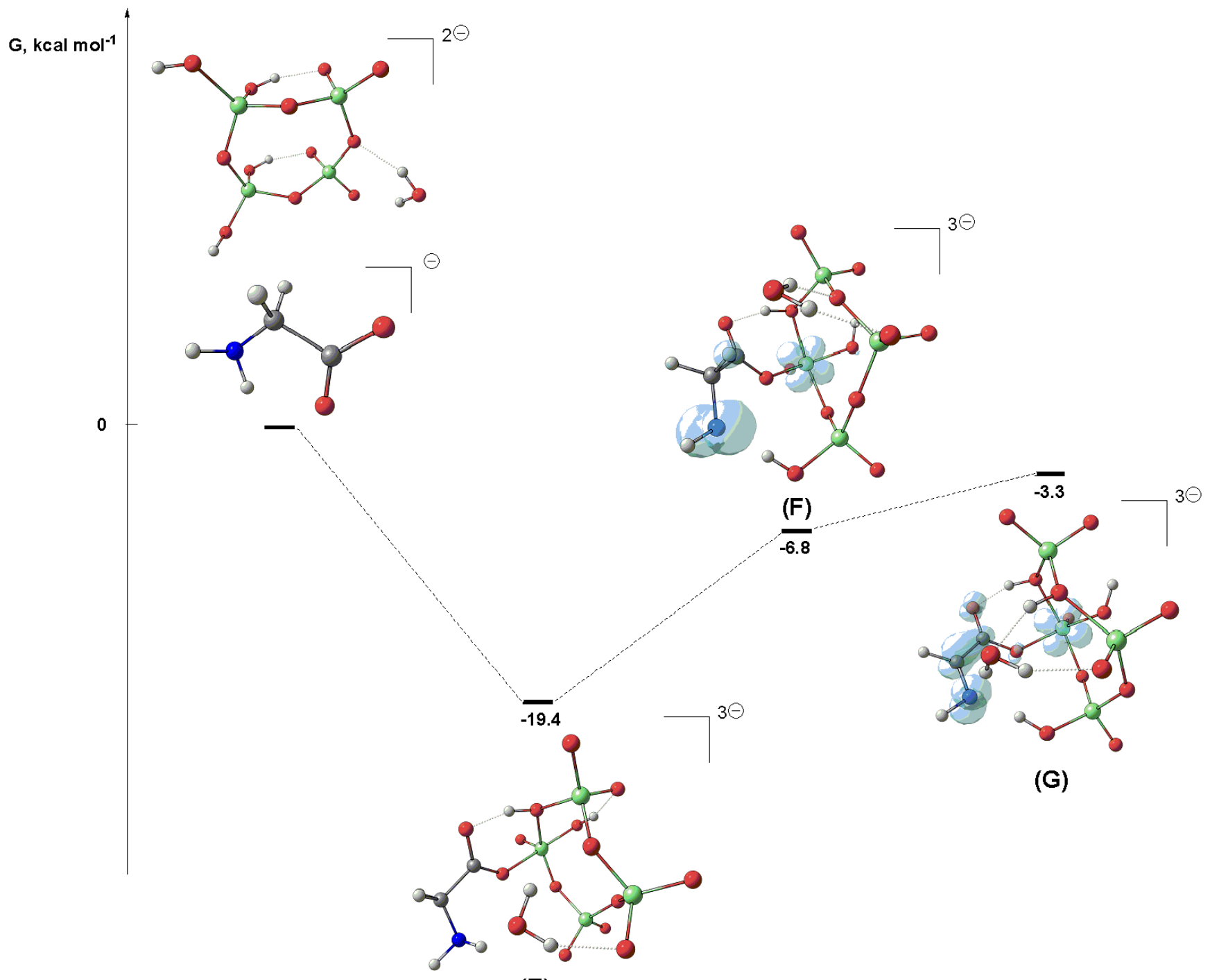

(E)

Figure 3. DFT-optimized structures of possible intermediates in the interaction of glycinate with $\left[\mathrm{V}_{4} \mathrm{O}_{10}(\mathrm{OH})_{2} \cdot \mathrm{H}_{2} \mathrm{O}\right]^{2-}$ and relative Gibbs energy values $\left(\mathrm{kcal} \mathrm{mol}^{-1}, \mathrm{~T}=343.15 \mathrm{~K}\right)$. C-PCM/ $/ \mathrm{BB} 97 \mathrm{X}$ calculations, water as continuous medium. Colour map: light grey, hydrogen; dark grey, carbon; red, oxygen; blue, nitrogen; green, vanadium, light blue, spin density surface (isovalue $=0.01$ a.u.). Cartesian coordinates of the DFToptimized structures are collected in a separated .xyz file. 